\title{
Konsep Diri Mahasiswa Program Studi Bimbingan Konseling IAIN Bukittinggi
}

Oleh:

\author{
AlfiRahmi.M.Pd
}

\author{
FadhilaYusri. M.Pd,Kons
}

\begin{abstract}
Abstrak
Pada dasarnya setiap individu memiliki konsep tentang dirinya. Konsep diri yang dimiliki oleh masing-masing individu itu berbeda. Konsep yang telah tertanam pada diri individu, akan mempengaruhi individu dalam berbagai aspek dikehidupannya. Konsep diri meliputi yang menyangkut fisik (materi dan bentuk tubuh), maupun psikis (sosial, emosi, moral dan kognitif) yang dimiliki seseorang.Konsep diri juga mempengaruhi individu dalam menghadapi berbagai permasalahan hidup. Mahasiswa termasuk individu unik yang memiliki konsep diri yang berbeda antara satu dengan lainnya. Konsep diri yang telah tertanam dalam diri individu itulah nantinya yang akan mempengaruhi diri individu, dalam mengambil suatu tindakan untuk menghadapi permasalahannya. Banyak kemungkinan yang akan dilakukan oleh individu dalam menghadapi permasalahanya. Konsep diri akan mempengaruhi tindakan yang dilakukan individu tersebut, apakah tindakan yang berdampak baik maupun sebaliknya.
\end{abstract}

\section{A. Pendahuluan}

Proses belajar, pengalaman dan hubungan sosial membuat setiap individu melakukan penilaian atas dirinya. Penilaian tentang diri yang telah menetap pada individu akan menjadi sebuah konsep mengenai dirinya. Konsep diri merupakan suatu penilaian mengenai keadaan diri sendiri yang relatif sulit diubah.

Meskipun individu lahir tanpa konsep diri, sebenarnya konsep diri itu mulai berkembang sejak individu lahir. Epstein, Brim, Blyth dan Traeger dalam Elida Prayitno (2002:119) mengemukakan konsep diri sebagai pendapat seseorang tentang dirinya sendiri baik yang menyangkut fisik (materi dan bentuk tubuh), maupun psikis (sosial, emosi, moral dan kognitif) yang dimiliki seseorang.

Pada dasarnya setiap individu memiliki konsep tentang dirinya. Konsep diri yang dimiliki oleh masing-masing individu itu berbeda. Pengalaman awal tentang kesenangan atau kesakitan, kasih sayang atau penolakan, membentuk konsep dasar untuk konsep diri yang akan datang. Konsep yang telah tertanam pada diri individu, akan mempengaruhi individu dalam berbagai aspek dikehidupannya. Konsep diri sangat mempengaruhi tingkah laku individu. Seperti diungkapkan oleh Wasti Soemanto (1998:185) mengemukakanbahwa konsep diri merupakan salah satu faktor penting yang mempengaruhi tingkah laku. 
Dalam menjalani kehidupan sehari-hari, individu selalu dihadapkan pada berbagai pilihan hidup. Bahkan sering terjadi bahwa segala yang diharapkan oleh individu tidak semuanya menjadi kenyataan. Untuk menghadapi kenyataan yang harus diterimanya, maka individu memperlihatkannya dengan berbagai kemungkinan. Ada individu yang dapat menerima keadaan ini dengan besar jiwa, namun banyak pula individu yang tidak mampu menghadapi keadaan seperti ini dengan baik. Individu yang tidak mampu menghadapi kenyataan hidup dengan baik inilah mereka yang mengalami permasalahan.

Permasalahan pada umumnya dialami oleh setiap individu yang merasa kehidupan efektifnya sehari-hari terganggu. Individu dari tingkatan usia yang berbeda akan mengalami permasalahan yang berbeda pula. Mahasiswa adalah salah satu individu dalam tingkatan usia tertentu. Tidak tertutup kemungkinan bahwa mahasiswa yang merupakan kaum akademisi juga memiliki permasalahan dalam kehidupan mereka.

Beban kredit semester yang terlalu banyak, tuntutan perkuliahan yang harus diselesaikan, ketidakselarasan hubungan dengan teman, hidup yang terpisah jauh dari keluarga, jarang menjalin komunikasi dengan orangtua, kondisi tempat tinggal yang kurang layak, sarana dan prasarana penunjang belajar yang kurang, tugas akhir yang tak kunjung selsesai, ketidakpastian karir di masa depan, serta banyak lagi permasalahan lain yang membebani pikiran mahasiswa.

Begitu banyak permasalahan yang dialami oleh mahasiswa selama menjalani masa perkuliahannya. Tidak semua kaum akademisi ini mampu menyelesaikan permasalahan hidup mereka dengan baik dan logis. Bahkan sering terjadi mereka memilih jalan yang brutal untuk menghadapi masalah mereka.

Dalam keadaan seperti ini konsep diri memiliki peranan. Konsep diri juga mempengaruhi individu dalam menghadapi berbagai permasalahan hidup. Mahasiswa termasuk individu unik yang memiliki konsep diri yang berbeda antara satu dengan lainnya. Konsep diri yang telah tertanam dalam diri individu itulah nantinya yang akan mempengaruhi diri individu, dalam mengambil suatu tindakan untuk menghadapi permasalahannya. Banyak kemungkinan yang akan dilakukan oleh individu dalam menghadapi permasalahanya. Konsep diri akan mempengaruhi tindakan yang dilakukan individu tersebut, apakah tindakan yang berdampak baik maupun sebaliknya.

Dalam kehidupan nyata berdasarkan pengamatan penulis, masingmasing mahasiswa berdasarkan pengalamannya, penilaian orang lain terhadapnya dan pemahamannya terhadap dirinya sendiri telah membentuk konsep tentang dirinya. Konsep diri yang terbentuk pada diri mahasiswa tersebut berbeda-beda, sesuai dengan latar belakang yang membentuk konsep diri tersebut.

B. KajianTeoriKonsepDiri

1. PengertianKonsepDiri 
MenurutDjaali (2000:166) yang mengemukakan bahwa konsep diri adalah pandangan seseorang tentang dirinya sendiri yang menyangkut apa yang ia ketahui dan rasakan tentang perilakunya, isi pikiran dan perasaannya, serta bagaimana perilakunya tersebut berpengaruh terhadap orang lain. Disini konsep diri yang dimaksud adalah pandangan seseorang tentang keadaan dirinya sendiri pada saat ini. Sejalan dengan itu, Slameto (1995:182) juga mengemukakan konsep diri adalah persepsi keseluruhan yang dimiliki seseorang mengenai dirinya sendiri. Konsep diri ini merupakan suatu kepercayaan mengenai keadaan diri sendiri yang relatif sulit diubah.

Menurut William D. Brooks dalam Jalaluddin Rahmat (2001:99) bahwa konsep diri adalah pandangan dan perasaan kita tentang diri kita. Persepsi tentang diri ini boleh bersifat psikologis, sosial dan fisik. Selanjutnya Jalaluddin Rahmat (2001:99) juga mengungkapkan bahwa dengan mengamati diri kita, sampailah kita pada gambaran dan penilaian diri kita, inilah yang disebut dengan konsep diri. Konsep diri bukan hanya sekedar mengamati tapi juga menilai diri kita sendiri.

Wasty Soemanto (1998:185) menjelaskan bahwa konsep diri adalah pikiran atau persepsi seseorang tentang dirinya sendiri. Dengan kata lain, konsep diri yaitu bagaimana orang melihat dirinya sendiri.

Hal ini dipertegas oleh Thantawy. R (2005:61) yang menyatakan bahwa konsep diri adalah gambaran deskriptif dan penilaian seseorang terhadap dirinya sendiri, bagaimana ia mempersepsikan dirinya sendiri. Konsep diri seseorang itu dibentuk atas dasar hasil pengalamannya dan hasil interaksinya dengan orang lain. Selanjutnya Epstein; Brim; Blyth and Traeger, dalam Elida Prayitno (2002:119) yang menyimpulkan bahwa konsep diri (self concept) sebagai pendapat atau perasaan atau gambaran seseorang tentang dirinya sendiri baik yang menyangkut fisik (materi dan bentuk tubuh) maupun psikis (sosial, emosi, moral, dan kognitif) yang dimiliki seseorang.

Dari berbagai pendapat tentang pengertian konsep diri yang dikemukakan di atas dapat disimpulkan bahwa konsep diri adalah pandangan atau pendapat seseorang tentang dirinya sendiri meliputi segala hal yang dimilikinya baik menyangkut fisik (materi dan bentuk tubuh) maupun psikis (sosial, emosi, moral dan kognitif).

\section{Jenis-jenis Konsep Diri}

Epstein, Brim, Blyth dan Traeger dalam Elida Prayitno (2002:119) yang mengemukakan bahwa konsep diri (self concept) sebagai pendapat atau perasaan atau gambaran seseorang tentang dirinya sendiri baik yang menyangkut fisik (materi dan bentuk tubuh) maupun psikis (sosial, emosi, moral dan kognitif) yang dimiliki seseorang.

1) Konsep diri yang menyangkut fisik

a) Konsep diri yang menyangkut materi 
Menurut Elida Prayitnokonsep diri yang menyangkut materi yaitu pendapat seseorang tentang segala sesuatu yang dimilikinya yang menyangkut harga benda.

Individu memiliki deskripsi yang sangat konkret tentang diri mereka yang didasarkan pada informasi umum, identitas, penampilan dan pemilikan yang ada pada diri mereka. Jadi konsep diri yang menyangkut materi adalah pendapat individu tentang harta benda atau kemampuan finansial yang dimilikinya, yang menjadi penilaian mereka atas dirinya sendiri.

b) Konsep diri yang menyangkut bentuk tubuh

Burns (1993:191) yang mengungkapkan bahwa tinggi tubuh, beratnya, corak kulitnya, pandangan matanya, proporsiproporsi tubuhnya, kemampuan fisik, ketahanan fisik, penampilan fisik menjadi sedemikian berkaitan erat dengan sikap terhadap dirinya sendiri dan perasaan tentang kemampuan pribadi serta kemampuan untuk menerima keadaan orang lain.

Perasaan yang dimiliki seorang individu tentang bentuk tubuhnya adalah serupa dengan perasaan yang ia pegang tentang dirinya secara umum. Burns menyimpulkan bahwa konsep diri yang tinggi berhubungan kuat dengan sikap penerimaan atas bentuk tubuh seseorang.Jadi konsep diri yang menyangkut tubuh adalah pendapat seseorang tentang bentuk tubuh yang dimilikinya.

2) Konsep diri yang menyangkut psikis

a) Konsep diri yang menyangkut sosial

Strang dalam Elida Prayitno mengutarakan bahwa konsep diri sosial adalah pendapat seseorang tentang bagaimana orang lain memandang dirinya tentang kemampuan sosialnya.Kesuksesan dalam pergaulan sosial ini dapat menambah kepercayaan diri individu dan akan mengembangkan konsep diri yang positif.

Seperti diungkapkan oleh Elida Prayitno bahwa individu yang memiliki konsep diri secara positif realistis, cenderung menampilkan tingkah laku sosial yang positif dalam arti menghormati, menghargai dan mengasihi orang lain. Jadi konsep diri yang menyangkut sosial adalah perasaan seseorang tentang kualitas hubungan sosialnya dengan orang lain.

b) Konsep diri yang menyangkut emosi

Burns mengemukakan bahwa perubahan emosional yang mempunyai konsekuensi terhadap perubahan filosofis juga dapat mempengaruhi konsep diri. Ekspresi emosi yang blak-blakan memberi kesan bahwa individu tidak mampu mengendalikan emosinya sendiri.

Menurut Elida Prayitno bahwa emosi positif dialami oleh individu yang kebutuhannya terpuaskan seperti kebutuhan 
mendapatkan status atau harga diri, diakrabi, sukses, mandiri dan filsafat hidup. Jadi konsep diri yang menyangkut emosi adalah pendapat seseorang tentang emosi yang dimilikinya, meliputi emosi marah, takut, cemas, kecewa, cinta, gembira, sedih, berani, benci dan emosi lainnya.

c) Konsep diri yang menyangkut moral

Burns mengungkapkan bahwa bagian moral dari konsep diri adalah sangat penting karena aspek moral ini merefleksikan penerimaan terhadap nilai-nilai dari masyarakat. Konsep diri moral berkembang karena kebutuhan untuk mendapatkan persetujuan dan menghindari penolakan dari masyarakat.

Jadi konsep diri yang menyangkut moral adalah pendapat individu mengenai moral yang dimilikinya dalam menjalankan kehidupan sebagai seorang anggota masyarakat.

d) Konsep diri yang menyangkut kognitif

Elida Prayitno menjelaskan bahwa konsep diri yang menyangkut kognitif adalah pendapat seseorang tentang kecerdasan yang dimilikinya baik dalam memecahkan masalah maupun dalam prestasi akademik. Selanjutnya, Slameto (1995:160 ) mengemukakan gaya kognitif dapat dikonsepsikan sebagai sikap, pilihan atau strategi yang secara stabil menentukan cara seseorang yang khas dalam berfikir dan memecahkan masalah.

Jadi konsep diri yang menyangkut kognitif adalah pendapat seseorang tentang kemampuan yang dimilikinya dalam memecahkan masalah dan dalam mencapai prestasi akademik.

\section{b. Faktor-faktor yang Mempengaruhi Konsep Diri}

M. Argyle, dalam Malcolm Hardy dan Steve Heyes (1998:138) menyatakan bahwa terdapat empat faktor yang sangat berkaitan yang berpengaruh terhadap perkembangan konsep diri, yaitu reaksi dari orang lain, pembandingan dengan orang lain, peranan seseorang dan identifikasi terhadap orang lain. Reaksi yang ditampilkan orang lain berpengaruh pada konsep diri kita.

Djaali (2000:169) yang mengungkapkan bahwa ada empat faktor yang mempengaruhi terbentuknya konsep diri, yaitu kemampuan, perasaan mempunyai arti bagi orang lain, kebajikan dan kekuatan. Konsep diri seseorang mula-mula terbentuk dari perasaan dihargai atau tidak dihargai oleh orang lain.

Selanjutnya Jalaluddin Rahmat (2001:101) yang menyatakan ada dua faktor yang mempengaruhi konsep diri, yaitu orang lain dan kelompok rujukan. Seperti di jelaskan Jalaluddin Rahmat bahwa bagaimana orang lain menilai diri saya, akan membentuk konsep diri saya. 
Dalam pergaulan bermasyarakat, kita pasti menjadi anggota berbagai kelompok. Jalaluddin Rahmat menerangkan bahwa ada kelompok yang secara emosional mengikat kita dan berpengaruh terhadap pembentukan konsep diri kita.

Disamping itu A. Suhaenah Suparno (2000:24) mengemukakan faktor-faktor yang mempengaruhi konsep diri diantaranya adalah pengalaman disekolah, pola atau praktek pengasuhan dan perkembangan fisik seseorang. Kualitas hubungan orang tua dan anak dapat menumbuhkan atau menghancurkan konsep diri. Setara dengan itu, James. F . Calhoun and Joan Ross Acocella (1990:76) menjelaskan empat faktor yang mempengaruhi konsep diri, yaitu orang tua, teman sebaya, masyarakat dan belajar.

Kemudian James. F . Calhoun and Joan Ross Acocella (1990:78) juga berpendapat bahwa orang tua, teman sebaya dan masyarakat memberitahu kita bagaimana mendefinisikan diri kita sendiri. Konsep diri juga merupakan hasil belajar, dimana pengalaman sangat berpengaruh pada konsep diri seseorang.

Jadi dari beberapa pendapat diatas dapat disimpulkan bahwa faktor yang mempengaruhi konsep diri adalah reaksi dari orang lain, perbandingan dengan orang lain, peranan seseorang, identifikasi terhadap orang lain, perasaan berarti bagi orang lain, kemampuan, kekuatan, kebajikan, orang lain, kelompok rujukan, orang tua, teman sebaya, masyarakat, belajar, atau pengalaman dan perkembangan fisik.

\section{c. Fungsi Konsep diri.}

Felker .D. dalam Elida Prayitno (2002:124) mengemukakan ada tiga fungsi utama konsep diri yaitu konsep diri sebagai pemeliharaan konsistensi internal, konsep diri sebagai interpretasi dari pengalaman dan konsep diri sebagai suatu kumpulan harapan-harapan.

Konsep diri sebagai pemeliharaan konsistensi internal bertujuan untuk menolak pendapat yang tidak benar tentang dirinya. M. Dimyati Mahmud (1989:54) yang mengungkapkan bahwa individu juga dapat membedakan antara pendapat sendiri tentang dirinya sendiri dengan pandangan pihak lain terhadap dirinya.

Kemudian, konsep diri juga berfungsi sebagai interpretasi dari pengalaman. Djaali (2001:167) juga menyatakan bahwa konsep diri berkembang dari pengalaman seseorang tentang berbagai hal mengenai dirinya terutama yang berkaitan dengan perlakuan orang lain terhadap dirinya.Individu akan memiliki konsep diri yang positif jika ia mempunyai pengalaman yang positif pula dalam hal itu.

Selain itu, konsep diri juga berfungsi sebagai suatu kumpulan harapan-harapan. Menurut Elida Prayitno (2002:125) konsep diri menentukan apa yang diharapkan individu untuk terjadi pada 
dirinya.Pengharapan mengenai unjuk kemampuan dasar kita, menolong menentukan apa yang akan kita capai dan seberapa jauh keberhasilannya.

Dari berbagai uraian diatas dapat disimpulkan bahwa ada tiga fungsi utama dari konsep diri yaitu sebagai pemeliharaan konsistensi internal, sebagai interpretasi dari pengalaman dan yang terakhir sebagai suatu kumpulan harapan-harapan.

d. Konsep diri positif dan konsep diri negatif.

1) Konsep diri positif

Sebagaimana diungkapkan oleh James. F. Calhoun and Joan Ross Acocella (1990:73) bahwa dasar dari konsep diri yang positif bukanlah kebanggaan yang besar tentang diri tetapi lebih berupa penerimaan diri.

Menurut E. Koswara (1991:139) bahwatingkah laku orang yang menerima dirinya adalah spontan, sederhana, tidak di buat-buat atau wajar dan tidak terikat. Orang dengan konsep diri positif mengenal dirinya dengan baik.

Jalaluddin Rahmat (2001:105) yang mengungkapkan bahwa orang yang memiliki konsep diri positif ditandai dengan lima hal:

1. Ia yakin akan kemampuannya mengatasi masalah

2. Ia merasa setara dengan orang lain

3. Ia menerima pujian tanpa rasa malu

4. Ia menyadari, bahwa setiap orang mempunyai berbagai perasaan, keinginan dan perilaku yang tidak seluruhnya di sukai masyarakat.

5. Ia mampu memperbaiki dirinya karena ia sanggup menggungkapkan aspek kepribadian yang tidak disenangi dan berusaha mengubahnya.

Karena konsep diri positif, individu dapat menerima dirinya sendiri apa adanya. Dan dengan menerima dirinya sendiri, dia juga dapat menerima orang lain.

Selanjutnya Mc. Candels dalam Elida Prayitno (2002:125) mengemukakan bahwa konsep diri yang sehat (positif) adalah sebagai berikut:

1. Konsep diri itu tepat dan sama dengan kenyataan yang ada pada diri individu itu sendiri.

2. Konsep diri itu ditandai oleh kefleksibelan atau keluwesan individu dalam menjalankan perannya di masyarakat.

3. Individu mampu mengatur dirinya sesuai dengan standar bertingkah laku yang telah menjadi miliknya sendiri, bukan diatur oleh keharusan dari orang lain. 
Untuk memiliki konsep diri yang positif, individu perlu memiliki pemahaman yang tepat dan realitis tentang siapa dirinya sebenarnya.

Jadi individu dapat memiliki konsep diri yang positif jika memiliki pemahaman tentang dirinya, mampu menerima dirinya apa adanya dan juga dapat menerima orang lain dengan baik.

\section{2) Konsep Diri Negatif}

Menurut William .D. Brooks dan Philip Emmert (1976) yang dikutip oleh Jalaluddin Rahmat (2001:105) ada empat tanda orang yang memiliki konsep diri negatif, yaitu peka pada kritik, responsif sekali terhadap pujian, cenderung merasa tidak disenangi orang lain dan bersikap pesimis terhadap kompetisi.

James .F. Calhoun and Joan Ross Acocella (1990:72) mengungkapkan individu yang berkonsep diri negatif memiliki pandangan yang benar-benar tidak teratur tentang dirinya sendiri, dan juga jika konsep diri itu terlalu stabil atau terlalu teratur, dengan kata lain kaku.

Menurut individu yang memiliki konsep diri negatif, informasi baru tentang diri hampir pasti menjadi penyebab kecemasan, rasa ancaman terhadap diri. Jalaluddin Rahmat (2001: 105) menyatakan bahwa bagi individu ini, koreksi seringkali dipersepsi sebagai usaha untuk menjatuhkan harga dirinya. Oleh karena itu, dia mengubah terus menerus konsep dirinya atau dia melindungi konsep dirinya yang kokoh dengan mengubah atau menolak informasi baru.

Jadi, dari penjelasan diatas dapat disimpulkan bahwa individu yang memiliki konsep diri yang negatif peka pada kritik, responsif terhadap pujian, merasa tidak di senangi orang lain, pesimis terhadap kompetisi, memiliki pandangan yang tidak teratur tentang dirinya, memiliki konsep diri yang kaku serta merasa cemas dan terancam bila mendengar informasi baru tentang dirinya.

\section{MetodologiPenelitian}

Penelitian ini merupakan penelitian kuantitatif dengan rancangan penelitian korelasional. A. Muri Yusuf (2005:83) yang menjelaskan bahwa penelitian korelasional merupakan suatu tipe penelitian yang melihat hubungan antara satu atau beberapa ubahan dengan satu atau beberapa ubahan yang lain. Dengan teknik korelasi seorang peneliti dapat mengetahui hubungan variasi dalam sebuah variabel dengan variasi yang lain. Tujuan utama melakukan penelitian korelasional adalah menolong menjelaskan pentingnya tingkah laku manusia atau untuk meramalkan sesuatu hasil.

Populasi dalam penelitian ini adalah seluruh mahasiswa prodi Bimbingan Konseling IAIN Bukittinggi yang masih aktif kuliah sebanyak 452 orang. 
Tabel 1

Jumlah Populasi Penelitian

\begin{tabular}{|c|c|c|}
\hline No & Tahun Masuk (BP) & Jumlah Mahasiswa \\
\hline 1 & $2007-2008$ & 17 orang \\
\hline 2 & 2009 & 65 orang \\
\hline 3 & 2010 & 105 orang \\
\hline 4 & 2011 & 105 orang \\
\hline 5 & 2012 & 160 orang \\
\hline \multicolumn{2}{|c|}{ Jumlah } & 452 orang \\
\hline
\end{tabular}

Sumber : Data AKAMA IAIN Bukittinggi

Penentuan jumlah sampel dalam penelitian ini dilakukan dengan menggunakan rumus yang dikemukakan oleh Hadari Nawawi, yang dikutip oleh Margono, yaitu :

$$
\mathrm{n} \geq \mathrm{pq}\left(\frac{\mathrm{z} 1 / 2}{\mathrm{~b}}\right) \quad 2
$$

Keterangan :

$\mathrm{n} \quad=$ jumlah sampel

$\geq \quad$ = sama dengan atau lebih besar

$\mathrm{p} \quad=$ proporsi populasi persentase kelompok pertama

$\mathrm{q} \quad=$ proporsi sisa dalam populasi

$\mathrm{Z}^{1 / 2}=$ derajat koefisien konfidensi pada $99 \%$ atau $95 \%$

$\mathrm{b}=$ persentase perkiraan kemungkinan membuat kekeliruan dalam menentukan ukuran sampel

Sementara penentuan sampel yang akan diambil berdasarkan besarnya sampel yang telah ditentukan akan dilakukan dengan menggunakan teknik stratified random samplingberdasarkan proporsi sampel pada masing-masing strata yang lebih dikenal dengan istilah proportional random sampling .

Populasi penelitian ini berjumlah 452 orang, 60 orang diantaranya sedang menyusun skripsi. Maka perhitungannya adalah sebagai berikut:

$\mathrm{F} \quad=\frac{60}{452} \times 100 \%=13,3 \%$ atau $P=0,133$

$\mathrm{q}=1,00-0,133=0,867$

$\mathrm{z}^{1 / 2}=1,96$ (pada derajat konfidensi $95 \%$ atau 0,05 )

$\mathrm{b} \quad=5 \%$ atau 0,05

berdasarkan perhitungan di atas, maka besarnya sampel dalam penelitian ini adalah :

$\mathrm{n} \geq 117,19$ dibulatkan 118 orang.

$$
\mathrm{n} \geq 0,133 \times 0,867\left(\frac{1,96}{0,05}\right) \quad 2
$$

Tabel 2

Jumlah Sampel Penelitian

\begin{tabular}{|c|c|c|}
\hline No & Tahun Masuk (BP) & Jumlah Mahasiswa \\
\hline 1 & $2007-2008$ & 5 orang \\
\hline 2 & 2009 & 18 orang \\
\hline 3 & 2010 & 29 orang \\
\hline
\end{tabular}




\begin{tabular}{|c|c|c|}
\hline 4 & 2011 & 29 orang \\
\hline 5 & 2012 & 37 orang \\
\hline \multicolumn{2}{|c|}{ Jumlah } & 118 orang \\
\hline
\end{tabular}

Alat ukur yang digunakan untuk mendapatkan data tentang konsep diriyaituangkekuisionerdengan menggunakan skala likert. Jawaban yang tepat menurut responden akan diberi tanda silang (X) pada salah satu pilihan jawaban yang disediakan, Jawaban yang disediakan yaitu Sangat Sesuai (SS), Sesuai (S), Kurang Sesuai (KS), Tidak Sesuai (TS), Sangat Tidak Sesuai (STS).

Penetapan skor untuk pilihan jawaban dalam bentuk skala likert sebagai berikut

Tabel 3

Skor Jawaban Responden

\begin{tabular}{|c|c|c|c|}
\hline No & Alternatif jawaban & Item Positif & Item Negatif \\
\hline 1 & SS & 5 & 1 \\
\hline 2 & S & 4 & 2 \\
\hline 3 & KS & 3 & 3 \\
\hline 4 & TS & 2 & 4 \\
\hline 5 & STS & 1 & 5 \\
\hline
\end{tabular}

Kuisioner yang telah disusun kemudian ditimbang oleh sejumlah ahli untuk melihat validitas isi dan uji keterbacaan instrumen.

Teknik analisis data yang digunakan dalam penelitian ini adalah sebagai berikut: Untuk melihat mean konsep diri responden digunakan rumus statistik sederhana sebagai berikut :

Mean, yaitu : $\mathrm{M}=\frac{\Sigma F X}{N}$

Standar deviasi, yaitu : $\mathrm{SD}=\sqrt{\left(\frac{\Sigma F X^{12}}{N}\right)}-\left(\frac{\Sigma F X^{1}}{N}\right)^{2}$

Range, yaitu : Range $=$ ST - SR

Keterangan :

$\Sigma \mathrm{FX}=$ Jumlah responden yang memilih (frekuensi) $\mathrm{x}$ nilai tengah pada setiap interval

$\mathrm{N}=$ Jumlah responden

$\mathrm{M} \quad=$ Mean

$\mathrm{SD} \quad=$ Standar deviasi

Range $=$ Rentangan dari skor

ST $=$ Skor tertinggi

SR $=$ Skor terendah

Untuk menetapkan kategori penelitian pada setiap item, indikator, sub variabel, dan variabel penelitian, peneliti menggunakan teknik persentase, yaitu dengan mencari persentase dari skor mean, dengan menggunakan rumus yang dikemukakan oleh Anas Sudijono (1998:25) yaitu:

$$
\% \text { Skor }=\frac{\text { SkorNyata }}{\text { SkorIdeal }} \times 100
$$


D. HasilPenelitian

Untukmelihatgambarankonsepdirimahasiswa

BK

IAIN

Bukittinggisecarakeseluruhandapatdilihatpada table berikut:

Tabel 1

KonsepDiriMahasiswa BK IAIN Bukittinggi

$\mathrm{N}=102$

\begin{tabular}{|c|c|c|c|c|c|c|c|}
\hline \multirow{3}{*}{$\begin{array}{l}\mathrm{N} \\
\mathrm{o}\end{array}$} & \multirow{3}{*}{ AspekKonsepDiri } & \multicolumn{6}{|c|}{ DeskripsiStatistik } \\
\hline & & \multicolumn{2}{|c|}{ Mean } & \multirow{2}{*}{$\begin{array}{l}\mathrm{S} \\
\mathrm{D}\end{array}$} & \multirow{2}{*}{$\begin{array}{l}\text { Ran } \\
\text { ge }\end{array}$} & \multicolumn{2}{|c|}{ Skor } \\
\hline & & $\begin{array}{l}\text { Sk } \\
\text { or }\end{array}$ & $\%$ & & & $\begin{array}{l}\mathrm{Mi} \\
\mathrm{n}\end{array}$ & $\begin{array}{l}\mathrm{Ma} \\
\mathrm{x}\end{array}$ \\
\hline 1 & $\begin{array}{l}\text { KonsepDiriBerkaitandenganaspek } \\
\text { materi }\end{array}$ & 3,5 & $\begin{array}{l}59, \\
9\end{array}$ & $\begin{array}{l}1, \\
1\end{array}$ & 4 & 1 & 5 \\
\hline 2 & $\begin{array}{l}\text { KonsepDiriBerkaitandenganaspekk } \\
\text { eadaanfisik }\end{array}$ & 3,5 & $\begin{array}{l}60, \\
7\end{array}$ & $\begin{array}{l}0, \\
9\end{array}$ & 4 & 1 & 5 \\
\hline 3 & $\begin{array}{l}\text { KonsepDiriBerkaitandenganaspeks } \\
\text { ocial }\end{array}$ & 3.9 & $\begin{array}{l}67, \\
2\end{array}$ & 1 & 4 & 1 & 5 \\
\hline 4 & $\begin{array}{l}\text { KonsepDiriBerkaitandenganaspeke } \\
\text { mosi }\end{array}$ & 3,6 & $\begin{array}{l}62, \\
3\end{array}$ & 1 & 4 & 1 & 5 \\
\hline 5 & $\begin{array}{l}\text { KonsepDiriBerkaitandenganaspek } \\
\text { moral }\end{array}$ & 3,6 & $\begin{array}{l}61, \\
6\end{array}$ & 1 & 4 & 1 & 5 \\
\hline \multirow[t]{2}{*}{6} & $\begin{array}{l}\text { KonsepDiriBerkaitandenganaspeki } \\
\text { ntelektual }\end{array}$ & 3,3 & $\begin{array}{l}56, \\
5\end{array}$ & 1 & 4 & 1 & 5 \\
\hline & Rata-Rata & 3,5 & $\begin{array}{l}61, \\
4\end{array}$ & 1 & 4 & 1 & 5 \\
\hline
\end{tabular}

E. Penutup

Konsepdirimahasiswa

BK

IAIN

Bukittinggisecaraumumdikategorikansedang.Halinidapatdilihatdaripersent ase rata-rata skorsebesar 61,4 \% dengan SD 1.

F. Kepustakaan

A. Muri Yusuf. 2005. Metodologi Penelitian. Padang: UNP press.

A.Suhaenah Suparno. 2000. Membangun Kompetensi Belajar. Jakarta: Dirjen Dikti Depdiknas.

Burns.R.B. 1993. Konsep Diri (Teori, Pengukuran, Perkembangan dan perilaku). (Alih Bahasa: Eddy). Jakarta: Arcan.

Calhoun, James. F dan Acocella, Joan Ross. 1990. Psikologi tentang Penyesuaian dan Hubungan Kemanusiaan (Alih Bahasa: R.S. Satmoko). Semarang: IKIP Semarang Press.

Davidoff, Linda.L. 1991. Psikologi Suatu Pengantar (alih Bahasa: Mari Juniati). Jakarta: Erlangga.

Djaali. 2000. Psikologi Pendidikan. Jakarta: Program Pascasarjana UNJ. 
Elida Prayitno.2002. Psikologi Perkembangan Remaja. Padang: UNP Press.

E. Koswara. 1991. Teori-teori Kepribadian. Bandung: Eresco.

Jalaluddin Rahmat. 2001. Psikologi Komunikasi. Bandung: PT. Remaja Rosdakarya.

M. Dimyati Mahmud. 1989. Psikologi Pendidikan. Jakarta: Dirjen Dikti Depdikbud.

Slameto. 1995. Belajar dan Faktor-faktor yang Mempengaruhinya. Jakarta: Rineka Cipta.

S. Margono. 2007. Metodologi Penelitian Pendidikan. Jakarta: Rineka Cipta.

Wasty Soemanto. 1998. Psikologi Pendidikan. Jakarta: Rineka Cipta. 